Research Article

\title{
Breast feeding and infant feeding practices among rural mothers in Goa
}

\author{
Jagadish Cacodkar $^{2}$, Shilpa Joglekar ${ }^{1 *}$, Anagha Dubhashi ${ }^{2}$
}

\author{
${ }^{1}$ Department of Preventive and social medicine, Goa Medical College, Goa, India \\ ${ }^{2}$ Department of Pediatrics, Goa Medical College, Goa, India
}

Received: 30 October 2015

Accepted: 11 December 2015

\section{*Correspondence:}

Dr. Shilpa Joglekar,

E-mail: drgeochild@gmail.com

Copyright: () the author(s), publisher and licensee Medip Academy. This is an open-access article distributed under the terms of the Creative Commons Attribution Non-Commercial License, which permits unrestricted non-commercial use, distribution, and reproduction in any medium, provided the original work is properly cited.

\begin{abstract}
Background: Breast feeding in India is universal. Integrated Management of Neonatal and Childhood illnesses (IMNCI) strategy recommended systematic assessment of breastfeeding and emphasized counseling of mothers, but the initiation of breast feeding is late and the colostrum is discarded. The aim of the study was to study infant feeding practices among rural Goan mothers, the various socio demographic factors influencing these feeding practices and study the practices among rural mothers towards health care of their children.

Methods: A cross sectional study was done among 307 rural mothers with children $<2$ years in the rural community under rural Health Training Centre Mandur which is located 16 kilometres from the capital city of Panaji, by doing a house to house oral interview. Analysis of collected data was done using SPSS and Chi-square test was applied in addition to proportions and percentages.

Results: Around $46.25 \%$ of the mothers fed colostrum to their newborns and $73.62 \%$ of the mothers' breastfed within 24 hours of birth. $37.59 \%$ of the mothers practiced exclusive breastfeeding (EBF) for the first six months. The association between literacy and prolonged duration of breastfeeding was found to be statistically significant $(\mathrm{p}<0.05)$. Cereal based diet was the commonest complementary feeding administered by $23 \%$ of the mothers.

Conclusions: The overall awareness about infant feeding practices such as early initiation of breastfeeding and feeding of colostrum among mothers was low despite the study area having quality antenatal and neonatal services.
\end{abstract}

Keywords: Infant feeding, Breast feeding, Colostrum, Rural Goa

\section{INTRODUCTION}

Infant feeding practices includes breast feeding and complementary feeding which influences the nutritional status of children below two years of age. Breast feeding is the most vital determinant factor of child survival. In India rural areas seems to be shaped with community social belief and cultural factors. ${ }^{1}$ The important infant feeding practices include initiation of breast feeding, breastfeeding on demand, artificial feeding, and complementary feeding. The WHO and UNICEF have developed the Global Strategy for Infant and Young Child Feeding (IYCF) which recognizes appropriate feeding practices to be crucial for improving nutritional status and decreasing infant mortality in all countries. WHO offers three recommendations for IYCF practices for children aged 6 to 23 months: continued breast feeding for 23 months or feeding appropriate calcium rich food if not breast fed, feeding solid or semisolid food for minimum number of times per day according to breastfeeding status and including foods from a minimum number of food groups per day according to the breastfeeding status. ${ }^{2}$ Breast feeding and a number of infant feeding practices differ amongst religions and communities. Goa has made remarkable progress in the health care sector. Mothers in rural areas get influenced 
by social, cultural and economic factors. ${ }^{3}$ This study was conducted to assess infant feeding practices in rural Goan mothers and to give suitable recommendations towards improved healthcare and health education towards better child health.

\section{METHODS}

\section{Study design}

This is a population based cross-sectional study for 1 year done to assess the knowledge, attitude of breast feeding, infant feeding and newborn healthcare practices of rural mothers of Goa.

\section{Study population}

This cross-sectional study was conducted in the rural community under sub health center Mandur and Carambolim. There were four villages under subcentre Mandur namely Dongrim, Mandur, Azossim and Neura. The villages under subcentre Carambolim include Corlim, Gaunsabhat, Carambolim and Dhulapi.

\section{Sample size and sampling technique}

The total population of the study area was 11,887 . The study population comprised of women having living children born in the preceding 2 years prior to commencement of the study, in order to minimize recall bias. List of such records were obtained from records of sub- health center, Anganwadis and RHTC Mandur. Only women native of the village were included in the study. Mothers unwilling to participate, mothers that came only for confinement and delivery to their parent's home and mothers unavailable despite three home visits were excluded from the study. Study population was 332 mothers with children $<2$ years.

\section{Data collection}

The proforma of the study was pretested among 30 such Goan mothers having children < 2years. Final proforma was then in administered to the study participants by means of oral interview through house to house visits. $307(97 \%)$ of the study population was interviewed. Data was analysed using Microsoft Excel and SPSS Windows version 14. Chi square and other relevant statistical tests were applied. Multiple logistic analyses was done using breast feeding, infant feeding as the dependent variable and maternal age, socio economic status, educational status, type of family as the independent variable. At the end of the interview, the mothers along with other family members were urged to follow the recommended practices on feeding, methods of complementary feeding and stop harmful traditional practices,

\section{RESULTS}

The study was carried out to assess feeding trends in the rural population of Goa and the results are as follows.

Table 1: Socio-demographic profile of mothers.

\begin{tabular}{|lll|}
\hline $\begin{array}{l}\text { Age } \\
\text { distribution(years) }\end{array}$ & Number & $\begin{array}{l}\text { Percentage } \\
(\%)\end{array}$ \\
\hline $15-20$ & 62 & 20.2 \\
\hline $20-25$ & 133 & 43.3 \\
\hline $25-30$ & 112 & 36.4 \\
\hline Educational status & & \\
\hline Graduate & 10 & 3.26 \\
\hline HSSC & 7 & 2.28 \\
\hline SSC & 85 & 27.69 \\
\hline Secondary & 101 & 32.90 \\
\hline Primary & 55 & 17.92 \\
\hline $\begin{array}{l}\text { No Formal } \\
\text { Education }\end{array}$ & 49 & 15.96 \\
\hline $\begin{array}{l}\text { Socioeconomic } \\
\text { status }\end{array}$ & 137 & 44.63 \\
\hline Group I (Upper) & 92 & 29.97 \\
\hline $\begin{array}{l}\text { Group II (Upper } \\
\text { middle) }\end{array}$ & 92.13 \\
\hline $\begin{array}{l}\text { Group III (Lower } \\
\text { middle) }\end{array}$ & 71 & 2.28 \\
\hline $\begin{array}{l}\text { Group IV (Upper } \\
\text { Lower) }\end{array}$ & 7 & 0 \\
\hline Group V (Lower) & 0 & 23 \\
\hline
\end{tabular}

\section{Feeding of colostrum}

As regards to colostrum feeding, we found that 142 $(46.25 \%)$ of all mothers had fed colostrum to their index child whereas $165(53.75 \%)$ discarded colostrum.

Table 2: Maternal education and feeding of colostrum.

\begin{tabular}{|c|c|c|c|}
\hline $\begin{array}{l}\text { Maternal } \\
\text { Education }\end{array}$ & $\begin{array}{l}\text { Feeding } \\
\text { colostrum \% }\end{array}$ & $\begin{array}{l}\text { Discarding } \\
\%\end{array}$ & Total \\
\hline $\begin{array}{l}\text { HSSC \& } \\
\text { above }\end{array}$ & $13(17.47)$ & $4(23.53)$ & 17 \\
\hline SSC & $44(51.77)$ & $41(48.23)$ & 85 \\
\hline Secondary & $51(50.50)$ & $50(49.50)$ & 101 \\
\hline Primary & $20(36.36)$ & $35(63.64)$ & 55 \\
\hline $\begin{array}{l}\text { No Formal } \\
\text { Education }\end{array}$ & $14(28.57)$ & $35(71.43)$ & 49 \\
\hline Total & $142(46.25)$ & $162(53.75)$ & 307 \\
\hline
\end{tabular}

Educational status of mothers and feeding of colostrum

Feeding colostrum to their infants was maximum 13 $(76.47 \%)$ in hssc and above educated group and lowest $14(28.57 \%)$ among those without any formal education. 
In our study out of 307 mothers, 133 (43.3\%) aged between 20-25 years, $112(36.4 \%)$ were in age Group 25 30 years, $62(20.2 \%)$ were in age Group 15- 20 years [Table 1]. Regarding the educational status, it was observed that ten mothers were graduate, seven were educated above HSSC, 85 were matriculate, 101 had secondary school level and 49 were illiterate [Table 2]. As per Modified Kuppuswamy's classification, 137 belonged to Group 1 (44.63), 92 in Group II (29.97), 71 in Group III (23.13) and 7 were in Group IV (2.28). There were no mothers in group V [Table 3]. Majority of the mothers were Hindus $253(82.41 \%)$ and the remaining were Catholics 54 (17.59\%), $255(83.06 \%)$ belonged to joint families and remaining 52 (16.94\%) were from nuclear families.

Table 3: Economic status and feeding of colostrum.

\begin{tabular}{|llll|}
\hline $\begin{array}{l}\text { Economic } \\
\text { status }\end{array}$ & $\begin{array}{l}\text { Feeding } \\
\text { colostrum }\end{array}$ & Discarding $\%$ & Total \\
\hline Group I & $80(58.39)$ & $57(41.61)$ & 137 \\
\hline Group II & $34(36.96)$ & $58(63.04)$ & 92 \\
\hline Group III & $28(35.90)$ & $50(64.10)$ & 78 \\
\hline Group IV & 0 & 0 & 0 \\
\hline Group V & 0 & 0 & 0 \\
\hline Total & $142(46.25)$ & $165(53.75)$ & 307 \\
\hline
\end{tabular}

$\mathrm{X}^{2}=14.69, \mathrm{df}=2, \mathrm{P}<0.01$

Feeding colostrum was seen in $80(58.39 \%)$ of group I, $34(36.96 \%)$ of group II and $28(35.90 \%)$ of group III.

Table 4: Type of family and feeding of colostrum.

\begin{tabular}{|lll|l|}
\hline $\begin{array}{l}\text { Type of } \\
\text { Family }\end{array}$ & $\begin{array}{l}\text { Feeding } \\
\text { Colostrum } \%\end{array}$ & Discarding & Total \\
\hline Joint & $115(45.10)$ & $140(54.90)$ & 255 \\
\hline Nuclear & $27(51.92)$ & $25(48.08)$ & 52 \\
\hline Total & $142(46.25)$ & $165(53.75)$ & 307 \\
\hline $\mathrm{X}^{2}=0.08, \mathrm{df}=1, \mathrm{P}<0.05$ & & \\
\hline
\end{tabular}

Table 5: Initiation of breast feeding.

\begin{tabular}{|lll|}
\hline Time (Hours) & Number & Percentage $(\%)$ \\
\hline$<1$ & 65 & 21.17 \\
\hline $1-6$ & 122 & 39.74 \\
\hline $6-12$ & 18 & 5.86 \\
\hline $12-24$ & 21 & 6.84 \\
\hline$>24$ & 81 & 26.38 \\
\hline
\end{tabular}

Most mothers initiated breast feeding within 6 hours after birth.

\section{Types of breast feeding}

$178(58 \%)$ practiced "on schedule" breast feeding whereas 129 (42\%) practiced "on demand" feeding.
Table 6: Duration of breast feeding for index child for mothers who have completed breast feeding.

\begin{tabular}{|lll|}
\hline Duration & Number & Percentage \\
\hline $0-3$ & 11 & 8.27 \\
\hline $3-6$ & 39 & 29.32 \\
\hline $6-9$ & 20 & 15.04 \\
\hline $9-12$ & 15 & 11.28 \\
\hline $12-15$ & 26 & 19.55 \\
\hline $15-18$ & 5 & 3.76 \\
\hline $18-21$ & 12 & 9.02 \\
\hline $21-24$ & 5 & 3.76 \\
\hline Total & 133 & 100 \\
\hline
\end{tabular}

Average duration of breastfeeding $=9.05$ months

133 mothers had discontinued breast feeding. Amongst these $50(37.59 \%)$ fed the babies for 0-6 months, 35 (26.32\%) fed the babies for 6-12 months and 48 (36.09\%) had fed for 12-24 months.

Table 7: Duration of breast feeding for index child for mothers who were currently breast fed.

\begin{tabular}{|ll|l|}
\hline $\begin{array}{l}\text { Duration } \\
\text { (months) }\end{array}$ & Number & Percentage (\%) \\
\hline$<6$ & 29 & 16.67 \\
\hline $6-12$ & 71 & 40.81 \\
\hline $12-18$ & 26 & 14.94 \\
\hline $18-24$ & 48 & 27.59 \\
\hline Total & 174 & 100 \\
\hline
\end{tabular}

Table 8: Age of artificial feeding.

\begin{tabular}{|lll|}
\hline Age (months) & Number & Percentage $(\%)$ \\
\hline $\begin{array}{l}\text { No artificial } \\
\text { feeding }\end{array}$ & 7 & 2.38 \\
\hline$<1$ & 97 & 31.60 \\
\hline $1-4$ & 187 & 60.91 \\
\hline$>4$ & 16 & 5.21 \\
\hline Total & 307 & 100 \\
\hline
\end{tabular}

Most mothers started giving some form of artificial feeds which were usually begun by 4-6 months.

Table 9: Age at weaning among infants.

\begin{tabular}{|lll|}
\hline Age (months) & Number & Percentage (\%) \\
\hline$<3$ & 22 & 7.58 \\
\hline $3-6$ & 191 & 65.86 \\
\hline $6-9$ & 70 & 24.14 \\
\hline $9-12$ & 1 & 0.35 \\
\hline $12-24$ & 6 & 2.07 \\
\hline Total & 290 & 100 \\
\hline
\end{tabular}


Table 10: Most commonly given weaning food.

\begin{tabular}{|l|l|}
\hline Type of weaning foods & Number \\
\hline Cereals & 271 \\
\hline Fruit juices & 193 \\
\hline Vegetable soups & 192 \\
\hline Baby formulae & 191 \\
\hline Fruit (whole) & 172 \\
\hline Cow/buffalo milk & 160 \\
\hline Dal & 157 \\
\hline Other liquids & 116 \\
\hline
\end{tabular}

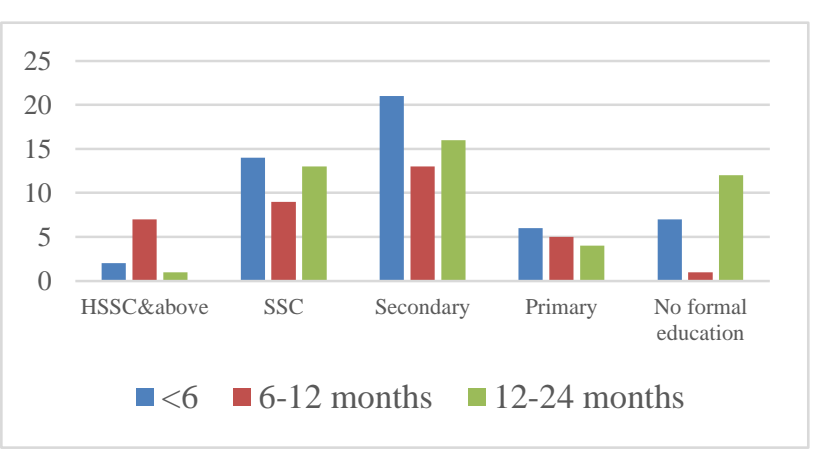

Figure 1: Maternal educational status and duration of breast feeding.

It is evident from the table that there is an association between mother's education and duration of breast feeding. Educational class affected the motivation to breast feed. However the type of family did not have any effect on the duration of breast feeding. Various reasons for stopping breast feeding were child's refusal, working mothers, current pregnancy, breast and nipple diseases and child not tolerated breast feeding.

\section{DISCUSSION}

The breast feeding practices prevailing in the community play important role in child's health. In this study it is revealed that $142(46.25 \%)$ of all mothers had fed colostrum to their index child whereas $165(53.75 \%)$ discarded colostrum. In other studies by Mahmood et al $84.6 \%$ of the mothers and $\mathrm{K}$ Madhu et al Jayant et al (2010), 84.6\% of the mothers fed colostrum. ${ }^{5,6}$ In contrast studied by Agarwal et al and Ghosh et al showed that the percentage of mothers who fed colostrum was only around $10 \%{ }^{7,8}$

Our study shows that the higher level of education, socioeconomic status and acceptance of colostrum as a beneficial entity go hand in hand. The other studies show the similar results. ${ }^{9}$ These study findings were statistically significant.

Early breastfeeding practices determine the successful establishment and duration of breastfeeding. It is recommended that children be put to the breast immediately or within one hour after birth. When a mother initiates breastfeeding immediately after birth, breast milk production is stimulated. During the first few days after delivery, colostrum, an important source of nutrition and antibody protection for the newborn, is produced and should be fed to the newborn while awaiting the production of regular breast milk. Prelacteal feeding giving liquids or foods other than breast milk prior to the establishment of regular breastfeeding deprives the child of the valuable nutrients and protection of colostrum and exposes the newborn to the risk of infection. $^{10}$

In our study, although the first hour feeding rates were less $(21.17 \%)$, almost three quarters of the babies (73.62\%) were breastfed with in the first $24 \mathrm{hrs}$. Similar study by Khan et al showed that $37.2 \%$ of the mothers initiated breastfeeding within one hour. ${ }^{11}$ A total of $19 \%$ of the mothers in the study did not breastfeed even 24 hours after the delivery as reported by Madhu et al. ${ }^{12}$

One third of the mothers $(36.09 \%)$ discontinued breastfeeding before six months of age and $26.32 \%$ of the mothers did so between 6-12 months of age. However $36.09 \%$ of the mothers continued breastfeeding for a period of 12 to 24 months. A study by Dongre et al showed $50 \%$ of mothers had feeding problems like feeding less than eight times in 24 hours and feeding other feeds other than breast milk. ${ }^{13}$

The exclusive breastfeeding rate was $61.26 \%$ at 4 months in the study in Karnataka by Banapurmath et al $17 \%$ of the mothers practiced exclusive breastfeeding in a study from Punjab. ${ }^{14,15}$ A study in Haryana only $15 \%$ of mothers practiced exclusive breastfeeding at 4 mo. ${ }^{16}$

It was found in our study that $300(97.62 \%)$ gave their infants some form of artificial feeds. In a similar study in Uttarakhand by Shaili Vyas et al $82 \%$ had started weaning. ${ }^{17}$ While corroborative findings like boys being weaned earlier than girls Katara et al in Vadodara. ${ }^{18}$ Malek et al higher education correlates with shorter period of breastfeeding. ${ }^{19}$ As per WHO and UNICEF guidelines promote Exclusive Breast Feeding for six months and nutritionally adequate and safe complementary food starting from end of six months along with continued breast feeding for two years. ${ }^{20}$ Complementary feeding term has replaced the term weaning and consist of appropriate, adequate, hygienically prepared, homemade mashed food given to a baby after six months of life when breast feeding alone is insufficient for the baby's nutritional needs. The target age for the complementary feeding is 6-24 months. ${ }^{21}$ Nearly $30-40 \%$ calories are derived from breast feeding during second year. Breast milk has larger fat content as compared to the complementary feeds hence breast feeding becomes richer source of energy and fats. Hence continuation of breast feeding along with complementary feeds is essential. 
In our study a large number of infants were given cereal based diet in the form of Kanji, soft cooked rice, mashed chapatti, and porridge. Other commonly given liquids were fruit juices, vegetable soups, infant formulae, whole fruit pulps, cows or buffalo's milk, dal and other liquids. Several other studies have made similar observations. ${ }^{22}$ Some studies have identified biscuits, sago, eggs and curd as common weaning food. This study reveals that mothers utilize a variety of weaning food. This can be due to the higher economic status of the study population and the availability of the various food items. Studies from different part of India have shown that tradition, cheapness, local availability determines the choice of weaning food.

\section{CONCLUSION}

Goa state is having advanced newborn care and low neonatal mortality but the findings from the study suggest the breast feeding and infant feeding practices overall awareness about infant feeding practices such as early initiation of breastfeeding and feeding of colostrum among mothers was low to the current recommendations of healthy practices for care of newborns. Universal practice of breastfeeding along with early initiation of breast feeding and prolonged duration of breast feeding is followed among rural mothers of Goa. Complementary feeding practices are similar to the current recommendations. National health program cannot be successful when there is huge gap of knowledge and awareness in the community about neonatal care in the rural area. This indicates the need for promoting correct practices for infant feeding in rural community.

Funding: No funding sources

Conflict of interest: None declared

Ethical approval: The study was approved by the Institutional Ethics Committee

\section{REFERENCES}

1. Indicators for assessing infant and young child feeding practices: of a consensus meeting held 6-8 November 2007 in Washington DC, USA. WHO, 2008. Available from: http://whqlibdoc.who.int/publications/2008/9789241 596664_eng.pdf. Last assessed on 2015 Aug 22.

2. Mukuria AG, Kothari MT, Abderrahim N. Infant and young Child Feeding Updates. Calverton, Maryland, USA: ORC Macro, 2006. Available from: http://www.measuredhs.com/pubs/pdf/NUT1/NUT1. pdf. Last assessed on 2015 Aug 22.

3. Iskandar MB, Costello C, Nasution Y. Initiation and duration of breast feeding in Indonasia. Asia Pac Popul J. 1990;5:89-112.

4. Kumar N, Gupta N, Kishore J. Kuppuswamy's Socioeconomic Scale: Updating Income Ranges for the year 2012. Indian J of Public Health. 2012;1(56):103-4.
5. Mahmood SE, Srivastava A, Shrotriya VP, Mishra P. Infant feeding practices in the rural population of north India. J Family Community Med. 2012;19(2):130-5.

6. Deshpande JD, Giri PA, Phalke DB, Phalke VD, Kalakoti P. Socio-cultural practices in relation to breastfeeding, weaning and child rearing among Indian mothers and assessment of nutritional status of children under five in rural India. Australasian Medical Journal AMJ. 2010;3(9):618-24.

7. Agarwal M, Udipi SA. The impact of nutritional education on child feeding practices among low income urban Indian mothers. Food and nutrition bulletin, The United Nations university press. 1989;11(1).

8. Ghosh S, Shah D. Nutritional problems in urban slums. Indian Pediatr. 2004;41:682-96.

9. Bhsnderi D, Choudhary SA. Community based study of feeding and weaning practices in under 5 children in semi urban community of Gujarat. National journal of community medicine. 2011;2(2):277-83.

10. Mukuria AG, Kothari MT, Abderrahim N. Infant and Young Child Feeding Update. 2006:23.

11. Khan AM, Kayina P, Agrawal P, Gupta A, Kannan AT. A study on infant and young child feeding practices among mothers attending an urban health center in East Delhi. Indian $\mathbf{J}$ Public Health. 2012;56:301-4.

12. Madhu K, Chowdary S, Masthi R. Breast feeding practices and newborn care in rural areas: A descriptive cross-sectional study. Indian J Community Med. 2009;34:243-6.

13. Dongre AR, Deshmukh PR, Rawool AP, Garg BS. Where and How Breast Feeding Promotion Initiatives should focus its attention? A study from rural Wardha. Indian $\mathrm{J}$ Community Med. 2010;35(2):226-9.

14. Banapurmath CR, Nagaraj MC, Banapurmath S, Kesaree N. Breastfeeding practices in villages of central Karnataka. Indian Pediatrics. 1996;33:477-9.

15. Gupta A, Gupta R. Obstetric and infant feeding practices in Punjab. Effect of educational intervention. Indian Pediatr. 1992;20:333-5.

16. Kapil U, Verma D, Narula S, Nayar D, Sachdev HPS, Shah AD, et al. Breastfeeding practices in ScheduleCaste communities in Haryana State, Indian Pediatrics. 1994;31:1227-32.

17. Vyas S, Kandpal SD, Semwal J, Chauhan S, Nautiyal V, et al. Trends in Weaning Practices among Infants and Toddlers in a Hilly Terrain of a Newly Formed State of India. International Journal of Preventive Medicine. 2014;6:741-8.

18. Katara PS, Patel SV, Mazumdar VS, Shringarpure K. A study on feeding practices among children aged 6 months to 2 years in urban slums of Vadodara. Indian J Matern Child Health. 2010;12:1-9.

19. Batal M, Boulghourjian C, Abdallh A, Afifi R. Public Health Nutrition. 2005;9(3):313-9. 
20. WHO/UNICEF. Global strategy for Infant and young child feeding, Geneva: World Health Organization, 2003.

21. Kramar MS, Kakuma R. The optimal duration of Exclusive Breast Feeding: A Systematic review. Geneva: WHO $2001 \quad$ (WHO/NHD/01, 08; $\mathrm{WHO} / \mathrm{FCH} / 01.23)$.
22. Khan ME. Breast feeding and weaning practices in India. Asia Pacific Population Journal. 1990;5(1):7188 .

Cite this article as: Cacodkar J, Joglekar S, Dubhashi A. Breast feeding and infant feeding practices among rural mothers in Goa. Int J Community Med Public Health. 2016;3:184-9. 